\section{PM0-156 PLASMA HBSAG LEVELS CORRELATE WITH LIVER CCCDNA IN TOLERANT CHILDREN WITH INFANCY ACQUIRED CHRONIC HEPATITIS B INFECTION}

doi:10.1136/gutjnl-2012-302514b.156

I Carey,* Y Zen, M J Bruce, M Horner, S Bansal, D Vergani, G Mieli-Vergani. Institute of Liver Studies and Transplantation, King's College Hospital, London, UK

Introduction Plasma HBsAg reflects the transcriptional activity of covalently closed circular (ccc) DNA within the liver rather than the absolute amount of cccDNA copies. Higher plasma HBsAg levels are reported among tolerant than immuno-active $\mathrm{HBeAg}$ positive chronic hepatitis $\mathrm{B}(\mathrm{CH}-\mathrm{B})$ patients. Only limited information is available on the interaction of plasma $\mathrm{HBsAg}$, expression of $\mathrm{HBsAg}$ and $\mathrm{HBcAg}$ within the liver and liver relaxed circular (RC) HBV DNA and cccDNA in patients with infancy-acquired $\mathrm{CH}-\mathrm{B}$.

Aims To evaluate whether there is a relationship between plasma $\mathrm{HBsAg}$ and HBV DNA levels and $\mathrm{HBsAg} / \mathrm{HBcAg}$ expression within the liver and liver RC HBV DNA and cccDNA in tolerant children with infancy-acquired $\mathrm{CH}-\mathrm{B}$.

Patients 23 children (eight males, median age 10.2 yrs) with infancyacquired $\mathrm{CH}-\mathrm{B}$ (all $\mathrm{HBeAg}+$ ) in tolerant stage underwent liver biopsy prior to antiviral therapy with lamivudine and interferon- $\alpha$. Methods Plasma HBsAg and HBV DNA levels were measured at therapy baseline by Abbott ARCHITECT ${ }^{\circledR}$ assay and real-time TaqMan PCR [both $\log _{10} \mathrm{IU} / \mathrm{ml}$ ]. Baseline liver RC HBV DNA and cccDNA was quantified by real-time TaqMan PCR [copies/ng genomic DNA]. Immunostaining of formalin-fixed, paraffinembedded liver specimens assessed $\mathrm{HBsAg}$ and $\mathrm{HBcAg}$ expression [\# of positive cells per 1000 hepatocytes]. Results are presented as median, range.

Results Baseline plasma HBsAg levels were 4.67 (3.7-5.1), HBV DNA was $8.2(7.1-8.9)$ both $\log _{10} \mathrm{IU} / \mathrm{ml}$ and ratio $\mathrm{HBsAg} / \mathrm{HBV}$ DNA 0.57 (0.44-0.65). Liver RC HBV DNA was 4.41 (2-5.3) $\log _{10}$ copies/ng genomic DNA and cccDNA was 363 (0.3-3632) copies/ng genomic DNA. HBsAg is predominantly expressed in cytoplasm focally associated with membranous staining, 2.9 (0-56.9) positive cells/1000 hepatocytes, in contrast to $\mathrm{HBcAg}$ expressing predominantly in the nucleus, $8.3(0.5-83.6)$ positive cells/1000 hepatocytes. There were positive bivariate Spearman correlations between plasma HBsAg levels and liver cccDNA ( $r=0.41, p=0.05)$, HBcAg liver expression and $\operatorname{cccDNA}(r=0.44, p=0.05)$, liver RC HBV DNA and $\operatorname{cccDNA}(\mathrm{r}=0.67, \mathrm{p}=0.04)$ and a trend towards correlation between plasma HBsAg and $\mathrm{HBsAg}$ liver expression $(\mathrm{r}=0.38$, $\mathrm{p}=0.07)$.

Conclusion Plasma HBsAg levels correlate with liver cccDNA in tolerant children with infancy-acquired chronic hepatitis B infection suggesting that plasma HBsAg levels acts as a surrogate marker of cccDNA within the liver in tolerant patients.

Competing interests I Carey grant/research support from: BMS, Gilead, Y Zen: None declared, M Bruce: None declared, M Horner: None declared, S Bansal: None declared, D Vergani: None declared, G Mieli-Vergani: None declared.

\section{PM0-157 hBSAG PLASMA LEVELS DECLINE HELPS TO PREDICT HBEAG LOSS BUT IS SIMILAR IN DIFFERENT NUCLEOS(T)IDE ANALOGUES REGIMENS}

doi:10.1136/gutjnl-2012-302514b.157

M Horner, M J Bruce, S Knighton, M Al-Freah, D Joshi, S Hughes, A Suddle, P M Harrison, K Agarwal, I Carey. Institute of Liver Studies and Transplantation, King's College Hospital, London, UK

Introduction The kinetics of serum $\mathrm{HBsAg}$ ( $\mathrm{qHBsAg}$ ) decline predict response to treatment with pegylated interferon (Peg-IFN) in chronic hepatitis B (CH-B). Whereas nucleos(t)ide analogue (NA) therapy is associated with a sharp decrease in serum HBV DNA level due to inhibition of the viral polymerase, only limited data are available comparing the effect of different treatment regimens on qHBsAg kinetics. This study compared serum qHBsAg and HBV DNA kinetics in patients with $\mathrm{CH}-\mathrm{B}$ receiving de-novo therapy with either tenofovir (TDF) $245 \mathrm{mg} /$ day, entecavir (ETV) $0.5 \mathrm{mg} /$ day or lamivudine $100 \mathrm{mg}$ /day plus adefovir $10 \mathrm{mg} /$ day $(\mathrm{LAM}+\mathrm{ADV})$.

Methods $205 \mathrm{CH}-\mathrm{B}$ therapy naïve monoinfected patients (75\% males, $21 \% \mathrm{HBeAg}$ positive, $21 \%$ cirrhotic, median age 36 years) were treated with TDF $(n=50)$, ETV $(n=62)$ or LAM + ADV $(n=93)$ for at least 12 months. We quantified qHBsAg (Abbott ARCHITECT ${ }^{\circledR}$ assay) and HBV DNA (real-time TaqMan PCR) in serial serum samples at baseline, months 3 (M3), 6 (M6) and 12 (M12)

Results Median qHBsAg levels were similar at each time-point and were not influenced by treatment regimen. No patient achieved HBsAg loss. More patients receiving TDF achieved optimal virological response (VR), defined as HBV DNA $<20 \mathrm{IU} / \mathrm{ml}$ ), at $\mathrm{M} 3$ compared to ETV and LAM+ADV ( $60 \%$ vs $43 \%$ vs $40 \%$, respectively; $\mathrm{p}=0.05)$ but not at M6 (76\% vs $74 \%$ vs $79 \%)$ and $\mathrm{M} 12(80 \%$ vs $82 \%$ vs $82 \%$ ). The proportion of patients achieving HBsAg decline $>0.5 \log _{10} \mathrm{IU} / \mathrm{ml}$ was higher in ETV cohort at M3 than in TDF and LAM $+\mathrm{ADV}(10 \%$ vs $2 \%$ and $2 \%$ respectively; $\mathrm{p}=0.05)$, but not at M6 (10\% vs $6 \%$ vs $5 \%)$ and M12 (12\% vs $10 \%$ vs $8 \%)$. HBeAg loss was more frequent in LAM+ADV and TDF groups than ETV $(47 \%$ vs $33 \%$ vs $6 \%$, respectively; $p=0.03$ ) and correlated with greater $\mathrm{qHBsAg}$ decline at all treatment time-points (M3: $r=0.47, p=0.04$; M6: $r=0.55, p=0.03 \& M 12: r=0.58, p=0.03)$. Patients achieving VR had higher qHBsAg levels (M3: 3.71 vs $3.29 \log _{10} \mathrm{IU} / \mathrm{ml}$; M6: 3.67 vs 3.24; and M12: 3.66 vs 3.24; all $\mathrm{p}<0.01$ ), slower $\mathrm{qHBsAg}$ decline and fewer patients with $\mathrm{qHBsAg}>0.5 \log _{10} \mathrm{IU} / \mathrm{ml}$ from baseline compared to those with detectable HBV DNA.

Conclusion Serum qHBsAg kinetics during therapy were a good predictor of $\mathrm{HBeAg}$ loss. However, antiviral therapy in $\mathrm{CH}-\mathrm{B}$ with nucleos(t)ide analogues in the first 12 months was similar between variable therapeutic approaches and there was no significant qHBsAg decline in contrast to HBV DNA suppression.

Competing interests M Horner: None declared, M Bruce: None declared, S Knighton: None declared, M Al-Freah: None declared, D Joshi: None declared, S Hughes: None declared, A Suddle: None declared, P Harrison: None declared, K Agarwal: None declared, I Carey grant/research support from: BMS, Gilead.

\section{PM0-158 RS12979860 CC GENOTYPE IS ASSOCIATED WITH BASELINE HIGH NUMBERS OF CD56BRIGHT NK-CELLS, LOW NUMBERS OF CD3-CD56-CD16 + CELLS, LOW IL-10 HCV-SPECIFIC PRODUCTION IN CH-C THERAPY RESPONDERS}

doi:10.1136/gutjnl-2012-302514b.158

I Carey,* M J Bruce, D Joshi, D Vergani, K Agarwal. Institute of Liver Studies and Transplantation, King's College Hospital, London, UK

Introduction IL28B gene single nucleotide polymorphisms (SNPs) rs12979860 and rs8099917 help to predict treatment response in chronic hepatitis $\mathrm{C}(\mathrm{CH}-\mathrm{C})$. Strong immune responses control HCV infection. Little is known on the association between IL28B SNPs, innate/adaptive immune responses in relation to Peg-IFN/ribavirin sustained virologic response (SVR) in $\mathrm{CH}-\mathrm{C}$.

Aims To evaluate the relationship between rs12979860 and rs8099917, pre-treatment frequency/phenotype of natural killer (NK) cells (innate immunity), HCV-specific immune responses (adaptive immunity), and SVR. 